till we left at 3 p.m. We went direct from Tarona to Sandakan, and as we steamed past the north end of the island I counted 18 jets of steam and smoke on the plain where in the morning there had only been two. The volcano itself was wrapped in smoke, and there were heavy clouds of smoke hanging over the plain. . . . . The Dutch controleur told us that they had already recovered 300 bodies, but that it was impossible to estimate the total loss. He said the other side of the island was worse, lava as well as mud having overflowed there, and that whole villages were buried. No lives were lost in Tarona itself, but forty men from there went into the jungle just before the eruption, and only one got back alive. . . W We got to Sanlakan at midnight on the $16 \mathrm{th}$, and stopped a day there. The eruption was distinctly heard at Sandakan, though it is nearly 500 miles from Sangir."

\section{THE WEST INDIAN FAUNA IN SOUTH FLORIDA.}

DR. C. H. MERRIAM has lately published a paper on "The Geographical Distribution of Life in North America " (Proc. Biol. Soc. Wash., April, I892), which should attract attention on account of the important problems discussed, and the interesting and somewhat novel views advanced. On pp. 49-55 there is a review of the faunal relations of Southern Florida, in which Dr. A. R. Wallace is severely criticized for having stated that Florida is, from a biological point of view, essentially North American, and totally distinct in character from Cuba and the Bahamas, from which it is separated by only a narrow strait. The phrase specially attacked is out of "Island Life," as follows: "Between frigid Canada and subtropical Florida there are less marked differences in the animal productions than between Florida and Cuba." 1

I well remember that some time ago, when I knew next to nothing of the West Indian fauna, this particular phrase seemed to me very erroneous. An American zoologist cannot fail to be struck with the presence of a colony of West Indian forms in Southern Florida, so distinct from the species and genera of the United States. Following Dr. Merriam's enumeration, we see nine genera of tropical birds, hundreds of tropical insects, a dozen or more land shells, many plants, and so forth. It would seem impossible to doubt that Southern Florida should be seferred to the West Indian faunal division in the face of such evidence.

But if we examine the matter from the point of view of a West Indian, who is searching for a fauna in Florida, which is identical, or nearly so, with that of the islands, things look very different indeed. Dr. Wallace's reference was to Florida as a whole, the term "subtropical" being used as descriptive of the State, not of the southern coast only, as used by Dr. Merriam. In the map given by Dr. Merriam, about nine-tenths of Florida are coloured orange, to indicate that they belong to the Lower Sonoran Region of the author. Now this, with the Upper Sonoran, which stretches into Canada, north of Lake Erie, forms the Sonoran, one of Dr. Merriam's primary divisions, the distinction of which from the Tropical region he has so well demonstrated. Furthermore, a large part of Canada is coloured blue on the map, to show that it belongs to the Transition Region between the Sonoran and the Borcal. Hence it appears, from Dr. Merriam's own map, and the statements throughout his paper, that by far the greater part of Florida is more allied faunally to portions of Canada than it is to the West Indies, so far exactly confirming the truth of Dr. Wailace's statement.

This will no doubt be readily admitted by Dr. Merriam, who bases his criticisms on the ground that Dr. Wallace had overlooked the existence of a West Indian fauna along the extreme south coast of Florida. We may, therefore, consider the evidence wherehy this limited portion of the State is placed in the Tropical division. For convenience, we may allude to this tract as Tropical Florida, using the term tropical to indicate the climate rather than the fauna.

In order to get at the necessary facts, I have compared the birds of the regions under consideration, using Cory's " Birds of the West Indies" as a guide to the ornithology of the several islands.

Dr. Merriam says that "no less than nine" genera of Tropical American birds inhabit Tropical Florida, and cites

I This statement is qualified by a footnote in the new edition of "Island Life," where the eristence of some West Indian forms is referred to.

NO. I I 93, VOL. 46] nineteen species or subspecies of Antillean birds living in the same area, but not further north.

I find on examining and comparing the West Indian statistics, ${ }^{1}$ that no less than 51 genera of West Indian land birds fail to reach Florida or any other part of North America. These genera are as follows :-

Mimocichla ; Cichlherminia ; Margarops; Ramphocinclus Cinclocerthia ; Leucopera ; Catharopera ; Microligea ; Teretistris : Glossiptila; Laletes; Dulus; Calliste ; Spindalis ; Nesospingus; Phanicophilus; Calyptophilus ; Saltator ; Loxigilla; Melopyr. rha; Loximitris; Sicalis ; Nesopsar; Elainia; Lazerencia; Blacicus; Nyctilius; Siphonorhis; Hemiprocne; Glaucis; Lampornis; Eulampis ; Aithurus; Thalurania ; Mellisuga; Doricha; Bellona; Sporadinus; Priotelus; Temnotrogon; Saurothera ; Hyetornis; Todus; Picumnuss ; Nesoceleus ; Ara; Chrysotis; Gymnasio; Rupornis; Regerhinus; Xiphidiopicus.

Those printed in ordinary type appear to occur in the West Indies only in the Lesser Antilles.

The number of West Indian species not reaching Florida is of course overwhelmingly great, but here the comparison would be unfair, owing to the large number of representative species, on different islands. In order to obtain a just estimate I have therefore made a list of the land birds inhabiting Cuba which do not occur in Tropical Florida, and the result shows one family (Todida), 18 genera, and 52 species. There are also a few sub-species.

The list is as follows:-

Icterus hypomelas.

Agelaius humeralis.

," assimilis.

Sturnella hippocrepis.

Quiscalus gundlachii. $"$ atroviolaceus.

Corvus nasicus.

Pitangus caudifasciatus.

* Saurothera merlini.

* Todus multicolor.

* Xiphidiopicus percussus. Centrurus superciliaris.

Colaptes chrysocaulosus.

* Nesoceleus fernandinæ.

* Mimocichla rubripes. schistacea.

Myiadestes Elizabeth.

Mimus gundlachi. B.

Polioptila lembeyi.

Dendroica petechia (race gundlachi) B. pityophila.

* Teretistris fernandinæ. fornsi.

* Coreba cyanea.

$$
\text { Geotrygon caniceps." }
$$

Myiarchus sagræ. B.

* Blacicus caribous. Tyrannus magnirostris. Antrostomus cubanensis. Cypselus phœnicolius.

* Hemiprocne zonaris. Calypte helenæ.

* Sporadinus riccordi. B.

* Priotelus temnurus. Petrochelidon fulva. Viveo gundlachi.

* Spindalis pretrei.

* Melopyrrha nigra.

* Pyrrhomitris cucullata. Euetheia olivacea.

* Ara tricolor.

Conurus euops.

* Chrysotis leucocephala. B. Asio stygius.

* Gymnavio lawrencii. Glaucidium siju. Accipiter gundlachi. fringilloides.

* Regerhinus wilsonii.

Columba corensis.

The two species of Columba are not definitely given as
an in Cory's work but I believe they occur there. Species Cuban in Cory's work but I believe they occur there. Species marked with an asterisk are of genera not reaching Florida; species marked " B" also occur in the Bahamas.

The Bahama Islands also have many birds that are not in Tropical Florida, including some genera, as Doricha (two species).

It is thus apparent that, so far as the birds are concerned, the arm of sea between Cuba or the Bahamas and the mainland has been very efficient in preventing the mingling of two faunæ, although a limited number of species have crossed it.

To give many other instances would unduly prolong this letter; but one may cite the land shells as a much more striking case. The land mollusca of $\mathrm{Cuba}$ and Florida are almost entirely distinct, the small number (about a dozen ${ }^{2}$ ) of West Indian forms which have reached Florida is really surprising, considering the favourable currents and the proximity of the two areas. Cuba contains numerous generic and subgeneric types, and hundreds of species, which have never reached Florida. ${ }^{3}$

On the other hand, even on the Florida Keys we get such

${ }^{\mathrm{I}}$ These might be modified in slight details by searching the most recent literature, but Cory's work (1889) is very complete up to the time it was published.

2 Dr. Merriam cites 20 on Dr. Dall's authority ; but several of these are not land shells, but belong to brackish or fresh water.

3 Thus, Cuba has considerably over 2 co species of operculate land-shells which have not reached Florida. 
North American types as the subgenera Polygyra and Mesodon of Helix (H. jejuna, No Name Key ; H. pustula, Cedar Keys; $H$. carpentcriana, Key Biscayne; H. cereolus, Indian Key, Key West, Egmont Key; $H$. septemvolva, Key West ; $H$ oppilata, Cedar Keys (but this is also a Yucatan species); $H$. uvulifera, plentiful on several Keys; H. auriculata, Cedar Keys).

How far the birds of Tropical Florida agree with those of the Sonoran region I do not know, having no list at hand from which to glean the facts; but inasmuch as they must greatly exceed nineteen, the number of Antillean forms quoted by Dr. Merriam, it is apparent that the character of the air-fauna cannot be so totally different from that of more northern regions as to justify the proposal to merge it in a different primary faunal division. Dr. Merriam gives a list of the birds which are supposed to be restricted to Southern Florida, comprising two species and seven sub-species ; this list emphatically confirms the view that the region in question is really North American (Sonoran), for of the two species, one belongs to a genus which does not occur in the West Indies, and the other to a North American genus which has no endemic West Indian species. The seven sub-species are all of North American species, and three of them belong to genera (Meleagris Cyanocitta, Sitta) which do not exist in the West Indies.

To sum up, the facts seem to be as follows:-The whole of Florida really belongs to the eastern division of the Nearctic region (or to the Sonoran region of Dr. Merriam), but along the southern coast, on land of comparatively recent origin, a number of West Indian forms have appeared, owing to the assistance of currents conveying floating trees, \&c., and to the proximity of Cuba and the Bahamas, which has permitted many birds and insects to fly across. These immigrants have formed a distinct colony, but not to any great extent, so far as can be learned, at the expense of the native fauna. The recent appearance of this colony is shown by the fact that (except somewhat doubtfully in the case of a few mollusca) there is at present no tendency to form new endemic species. Mr. Schwarr, who was so impressed with the great number of West Indian insects he found in this region, specially mentions that there were no endemic forms.

The northward spread of this colony has doubtless been largely prevented by climate, as stated by Dr. Merriam; but doubtless also quite as largely owing to the competition of the Sonoran fauna, for, as Dr. Merriam has himself put it in another connection, "the sustaining capacity of a region is limited; hence such a thing as overcrowding, in the sense of greatly increasing the number of organisms a region can support, is an impossibility."

If climate had been the only barrier, then Tropical Florida should have a fauna like that of Cuba; but so far from doing so, it is still essentially Nearctic, notwithstanding the existence of a very important and interesting West Indian colony. At best it is a transition region.

Under the guidance of Dr. Merriam, researches into the geographical distribution of North Americ in birds and mammals are being energetically carried on; and if I am not mistaken in the above-stated opinions, no doubt information will in due course accumulate that will cause him to withdraw from the position here criticized, and to admit that Dr. Wallace was, in the main, perfectly correct.

Institute of Jamaica, Kingston, Jamaica, July $3 \mathbf{I}$.

\section{"A NEW SECT OH HERO-WORSHIPPERS."}

UNDER this title, the Japan Mail describes a curious Society, established in Japan, in honour of Isaac Newton, and which is not a new scientific association so much as a new cult. The day of all the year to the members is Christmas Day, being that on which in 1642 the immortal Newton was born. The constitution is of the simplest. The professors, graduates, and students of the mathem itical, astronomical, and physical classes of the Tokio University are ex officio members; once a member always a member; and there are no others. The Society was launched as one for und $\rightarrow$ rgraduates by Messrs. F ijisawa, Tanaka and Tanakadate, the first brilliant triumvirate of mathematical graduates which the $\Gamma$, kio University gave to the world. In its early days it met in the students' dormitory. But as the undergraduates developed into graduates and assistants, the professors themselves were drawn into the fold, and a more suitable assembly hall was found in the University Observatory. Now, however, that building is devoted to seismological pursuits. At Christmas, 1890 , or Newtonmas, 248 , for the first time, the members of the Nezotonkai, or Newton Association, met in the Physical Laboratory of the Imperial University, to hear each other talk, to distribute appropriate gifts, and to lengthen out the small hours with laughter and good cheer. The Society has no President : a portrait of the august Sir Isaac presides over the scene. It keeps no written records, no minutes ; but its traditions are simple, and easily handed down from year to year. The entertainment provided is the work of the second-year students, assisted by those of the first year. Each professor is expected to make a little speech, which is sometimes historical, sometimes whimsical, as the individual spirit may prompt; but it must not be singgestive of the background of a blackboard. The meeting in fact is essentially social ; and in the preparation of the magic lantern slides, the committee of management lay themselves out for frolic and jest. The picture may represent a comical incident familiar to most of the members, or it may be a pictorial conundrum to guess. It was a fine humour, for instance, which gave a caricature of one student notorious for his indefatigable asking of quesiions. This youth was shown labouring under a shoulder beam, from which hung two buckets filled to overflowing with points of interrogation; while in the background was seated one of the professors, perfectly aghast as this mathematical labourer approached with his load. After the magic lantern exhibition comes the lottery for presents. This is a great feature, productive of much merriment. Each person draws a paper, which may be blank, but usually has a name on it. This name may be one of the illustrious living, or the still more illustrious dead. Corresponding to each name is an article, which, with all solemnity, is presented to the holder of the paper. The connection between the article and the name is more or less symbolic, or it may rest on a far-fetched pun, to which the Japanese language readily lends itself. Usually the jokes are very technical; but occasionally they appeal to a circle more wide than mathematical. Thus the drawer of "Newton" got an apple, and the drawer of "Franklin" a kite. "Herschell" (Sir John) was represented by a sprig of Nanten ("southern heavens," which he surveyed) ; "Archimedes," by a naked doil supposed to be returning from the bath; while the holder of "Kant-Laplace," got a puff of tobacco smoke blown in his face, symbolic of the nebular hypothesis. Some time ago it was pointed out by a European member of the Kai that in holding the "Newtonmas" on Christmas Day the members were guilty of a chronological crime hardly to be excused in men trained in the accurate school of Newton. For although he was registered as being born on Christmas Day, I642, it was Christmas Day, old style. In all strictness he was born on January 5,1643 . But the great convenience of having the fîte at the beginning rather than towards the end of the winter vacation, and the avoidance of clashing with Japanese New Year festivities, were sufficient to outweigh all other considerations whatsoever. Besides, did not Newton himself hold his birthday on Christmas Day? Why, then, should his admirers hold it on any other? After all, concludes the Yokohama journal, the peculiar interest of the "Newtonmas" lies in its existence. Only to the hero-worshipping Japanese has it occurred thus to pay honour to the memory of the greatest mathematical sage of all time. Very few English-speaking naturalists, to use the word in its widest and legitimate sense, are even aware that Christmas Day in $\mathbf{1} 642$ beheld the birth of Newton. It is possible that nearly fifty years ago a bicentenary fête was held in Cambridge ; and it is very probable that about fifty years hence Newton's tercentenary will be celebrated in Englandperhaps over all the civilized world. But an annual celebration by a Newton Club outside Japan is a thing not to be dreamed of, unless Japan influences the hero-worshipping instinct of the Western people as profoundly as she has influenced their æsthetic taste.

\section{SCIENTIFIC SERIALS.}

Royal Society of Victoria, Vol. 3 (N.S.), Proceedings, Part I. contains Nutes on West Australian oology, by A. J. Campbell (Pls. I and 2); On some Victorian fishes, with descriptions of Cristiceps wilsoni, C. phillipi, Syngnathus phillipi, and Trip-

No. I I 93, vOL. 46] 